\title{
Energy Efficiency Opportunities in the Brewery Industry
}

\author{
Ernst Worrell \\ Staff Scientist
}

\author{
Christina Galitsky \\ Principal Research Associate Science \& Engineering Associate \\ Lawrence Berkeley National Laboratory \\ MS: 90-4000, One Cyclotron Road, Berkeley, CA 94720, USA \\ Nathan Martin
}

\begin{abstract}
Breweries in the United States spend annually over $\$ 200$ Million on energy. Energy consumption is equal to $3-8 \%$ of the production costs of beer, making energy efficiency improvement an important way to reduce costs, especially in times of high energy price volatility. After a summary of the beer making process and energy use, we examine energy efficiency opportunities available for breweries. We provide specific primary energy savings for each energy efficiency measure based on case studies that have implemented the measures, as well as references to technical literature. If available, we have also listed typical payback periods. Our findings suggest that there may still be opportunities to reduce energy consumption cost-effectively for breweries. Major brewing companies have and will continue to spend capital on cost effective measures that do not impact the quality of the beer. Further research on the economics of the measures, as well as their applicability to different brewing practices, is needed to assess implementation of selected technologies at individual breweries.
\end{abstract}

\section{INTRODUCTION}

As U.S. manufacturers face an increasingly competitive environment, they seek out opportunities to reduce costs. With today's fluctuating energy prices, often this means investment into cost-effective energy saving technologies and practices that will reduce operating costs while maintaining or increasing product quality and yield. Energy-efficient technologies often include additional benefits, such as increasing productivity or achieving future or current environmental goals, thus reducing the regulatory "burden". Voluntary government programs aim to assist industry to improve competitiveness through increased energy efficiency and reduced environmental impact. Energy $\operatorname{Star}^{\circledR}$, a voluntary program operated by the U.S. Environmental Protection Agency in coordination with the U.S. Department of Energy, stresses the need for strong and strategic corporate energy management programs. Energy Star ${ }^{\circledR}$ provides energy management tools and strategies for successful programs. The current paper reports on research conducted to support Energy Star ${ }^{\mathbb{B}}$ and its work with the beer industry. This research provides information on potential energy efficiency opportunities for breweries. Besides technical information, Energy $\mathrm{Star}^{\circledR}$ is developing additional energy management tools to facilitate stronger corporate energy management practices in U.S. industry, including plant energy and productivity benchmarks. These benchmarks will serve as an important tool for industry to determine additional energy performance opportunities.

The U.S. brewery sector is composed of about 500 companies and over 2,000 brewing establishments, producing about $\$ 20$ billion worth of shipments (1). The sector is increasingly moving to economies of scale with large establishments of more than 250 employees accounting for roughly half of the value added in the sector. Three companies, AnheuserBusch, Miller and Coors account for $83 \%$ of total U.S. production. U.S. Production averages roughly 200 million barrels per year. Beer in bottles and cans dominates the market; canned beer accounts for half the value of shipments for the industry ( $\$ 9.6$ billion), and bottled beer accounts for an additional third ( $\$ 6.2$ billion). Light beer currently has a third of market share and continues to grow. The craft-brewing segment is also growing, although the base of production is still relatively small, while growth in domestic beer production for the main brands has been relatively flat.

\section{BEER MAKING}

The brewing process uses malted barley and/or cereals, unmalted grains and/or sugar/corn syrups (adjuncts), hops, water, and yeast to produce beer. All brewers in the U.S. use malted barley as their 
principal raw material. Depending on the location of the brewery and incoming water quality, water is usually pre-treated. Reverse osmosis, zeolite softening, lime softening, carbon filtration or other types of filtering systems are used to treat brewery water streams.

The first step in brewing is milling, which takes place when malt grains are transported from storage facilities and milled in either a wet or dry process in order to ensure that one can obtain a high yield of extracted substances. Sometimes, milling is preceded by steam or water conditioning of the grain.

The mixture of milled malt, gelatinized adjunct, and water is called mash. The purpose of mashing is to obtain a high yield of extract (sweet wort) from the malt grist and to ensure product uniformity. Mashing consists of mixing and heating the mash in the mash tun, and takes place through infusion, decoction or a combination of the two. During this process the starchy content of the mash is hydrolyzed producing liquor called sweet wort. In the infusion mashing process, hot water between $160-180^{\circ} \mathrm{F}\left(71-82^{\circ} \mathrm{C}\right)$ is used to increase the efficiency of wort extraction in the insulated mashing tuns. In decoction mashing, a portion of the mashing mixture is separated from the mash, heated to boiling, and re-entered into the mash tun. This process can be carried out several times, and the overall temperature of the wort increases with each steeping. Part of this mash is evaporated. Energy requirements are estimated at 12-13 $\mathrm{kBtu} /$ barrel for medium sized breweries (5). The type of mashing system used depends on a number of factors such as grist composition, equipment, and type of beer desired. Decoction mashing appears to be the preferred system in North America. Infusion mashing (characteristic of British ale brewers) is less energy intensive requiring roughly $8-10 \mathrm{kBtu} / \mathrm{barrel}$ of fuel.

Following the completion of the mash conversion, the wort is separated from the mash, commonly using a combined mashing vessel, lauter tun or a mash filter. In the combined mashing vessel, the wort run off is directed through a series of slotted plates at the bottom of the tun. This tends to be the slowest wort separation system although it is the lowest cost in terms of capital outlay. With the use of the lauter tun, the converted mash is transferred to a lautering vessel where the mash settles on a false bottom and the wort is strained from the solid grain particles. Lautering is a screening procedure that retains the malt residue from mashing on slotted plates or perforated tubes so that it forms a filtering mass. The wort flows through the filter bed. In both the combined mashing vessel and the lauter tun the grains are also sparged (i.e. sprayed and mixed) with water to recover any residual extract adhering to the grain bed. The extracted grain is most often used as animal feed. In a mash filter, the mash is charged from the mash mixer. The filter is fitted with fine pore polypropylene sheets which forms a tight filter bed and allows for very high extract efficiency. The quality of the filtered wort may be affected through the use of a mash filter process and may not be applicable for all types of brewing.

The next step, wort boiling, involves the boiling and evaporation of the wort (about a 4-12\%evaporation rate). The boil is a strong rolling boil and is the most fuel-intensive step of the beer production process. Energy consumption is estimated at 44-46 $\mathrm{kBtu} / \mathrm{b}$ arrel for conventional wort boiling systems. The boiling sterilizes the wort, coagulates grain protein, stops enzyme activity, drives off volatile compounds, causes metal ions, tannin substances, and lipids to form insoluble complexes, extracts soluble substances from hops, and cultivates color and flavor. During this stage, hops, which contain resins and essential oils, can be added. Components of the hop resins are modified during the wort boiling process to impart bitterness to the beer. Hop variety and timing of hop additions to the kettle all play a part in the characteristic of the bitter quality that is developed during the boiling process. When aroma hops are used, essential oils are steam distilled during the boiling process. Components from the essential oils are either retained in the kettle (reflux) or are allowed to escape up the brewkettle stack. Hops can be fully or partially replaced by hop extracts, which reduce boiling time and remove the need to extract hops from the boiled wort. If hops are used, they may be removed after boiling with different straining devices in a process called hop straining. Some breweries sparge the spent hops with water and/or press the hops to recover wort. The boiled wort is clarified through sedimentation, filtration, centrifugation, or whirlpool. Whirlpool vessels are most common in the U.S. After clarification the wort is most often cooled using plate heat exchangers. Some brewers aerate the wort before cooling to drive off undesirable volatile organic compounds. A secondary cold clarification step is used in some breweries to settle trub in the wort.

Once the wort is cooled it is aerated or oxygenated and blended with yeast on its way to the fermenter. During fermentation the yeast metabolizes the fermentable sugars in the wort to produce alcohol, carbon dioxide, and a range of secondary metabolites, some of which are significantly flavor active. The 
process also generates significant heat that must be dissipated in order to avoid damaging the yeast. Fermentation temperatures vary significantly and are very dependant upon the type of yeast bring utilized. Ale yeasts ferment at warmer temperatures than lager yeasts. Fermenters are cooled by coils or cooling jackets. In a closed fermenter, carbon dioxide can be recovered and later re-used. Fermentation time will vary from a few days (warmer temperatures with ale yeasts) to 10 days (colder temperatures with lager yeasts). The rate is dependent on the yeast strain, fermentation parameters and taste profile that the brewer is targeting.

At the conclusion of the primary fermentation process, yeast is removed by means of an oscillating sieve, suction, conical collector, settling, or centrifugation. Some of the yeast is reused while other yeast is discarded. Some brewers wash their yeast.

Some brewing methods require a second fermentation, where sugar or fresh yeasted wort is added to start the second fermentation. This is known as kraeusening. The tank is sometimes vented for a period of time to allow the escape of unwanted volatile compounds (primarily sulfur compounds) and the tank is then allowed to pressurize. The carbon dioxide produced in this stage dissolves in the beer, requiring less carbonation during the carbonation process. Carbonation takes place in the first fermentation also. Yeast is once again removed with either settling or centrifugation or filtration. This second fermentation takes place in the aging tank in some breweries.

Beer aging or conditioning is the final step in producing beer. The beer is cooled and stored in order to settle yeast and other precipitates and to allow the beer to mature and stabilize. For beers with a high yeast cell count, a centrifuge may be necessary for pre-clarification and removal of protein and complex tannin materials. Different brewers age their beer at different temperatures in order to achieve the taste profile for their brands. This ranges from $20^{\circ} \mathrm{F}$ to $50 \mathrm{~F}$. Beer is held at conditioning temperature for different times based on the brewers taste requirements. This can vary from several days to more than a month. In addition, Anheuser-Busch uses the traditional Beechwood Aging Process during lagering. This process consumes a large amount of water and energy in preparation of the chips.

The beer is then chillproofed and filtered. A kieselguhr (diatomaceous earth) filter is typically used to remove any remaining yeast. Some brewers use stabilizing agents for chillprooofing. Coloring, hop extracts, and flavor additives can be dosed into the beer at some breweries. The beer's $\mathrm{CO} 2$ content can also be trimmed with carbon dioxide that was collected during fermentation. The beer is then sent to a bright (i.e. filtered) beer tank before packaging. In high gravity brewing specially treated water would be added during the conditioning stage. This can be a significant volume, as high as $50 \%$.

Finally, the beer must be cleaned of all remaining harmful bacteria before bottling. One method to achieve this is pasteurization, where the beer is heated to $140^{\circ} \mathrm{F}\left(60^{\circ} \mathrm{C}\right)$ to destroy all biological contaminants. Different pasteurization techniques are tunnel or flash pasteurization. Energy requirements for pasteurization can vary from 19-23 kWh per 1000 bottles for tunnel pasteurization systems. Other estimates are 14-20 kBtu/barrel (5). An alternative approach is the use of sterile filtration. However, this technology is heavily reliant on cleaning, followed by hot water sterilization cycles, and some believe these systems do not lead to net energy savings.

A large amount of water is used for cleaning operations. The brewing process is reliant upon pure culture fermentation, and as such, requires meticulous microbiological sanitation practices. Incoming water to a brewery can range from 4-16 barrels of water per barrel. Wastewater is usually between 1.3 and 2 barrels less than water use and contains biological contaminants. The main solid wastes are spent grains, yeast and spent hops and diatomaceous earth. Spent grains are estimated to account for about $16 \mathrm{~kg} / \mathrm{barrel}$ of wort (36 lbs/barrel), while spent yeast is an additional $2-5 \mathrm{~kg} / \mathrm{barrel}$ beer (5-10 lbs/barrel) (5) with the exception of diatomaceous earth. These waste products primarily go to animal feed. Carbon dioxide and heat are also given off as waste products.

\section{ENERGY USE}

Breweries are a part of the Standard Industrial Classification (SIC) group Food and Kindred Products (group 20), which consumed 1,585 TBtu, equal to roughly $7 \%$ of total manufacturing primary energy in 1994 (2). Of the food processing energy use, breweries consumed about $4 \%$, equal to $67 \mathrm{TBtu}$. In 1998, total energy expenditures in the malt beverage industry group totaled $\$ 211$ million (3). Although overall data exists for more recent years, 1994 is the last year where detailed energy consumption and energy expenditure statistics were published for the breweries sector by the Energy Information Administration (EIA). 
Within the breweries sector, natural gas and coal account for about $60 \%$ of the total primary energy, and are mainly used for boiler fuel and for onsite electricity generation. Net electricity consumption, including losses, was $36 \%$ of primary energy requirements (see Table 1). Corresponding 1994 energy expenditures are also shown in Table 1 . Note that electricity expenditures account for $56 \%$ of the total, even though primary consumption is $36 \%$. We estimate that total energy expenditures account for roughly $3-8 \%$ of total production costs, based on data from the United Kingdom for breweries of similar design to those in the U.S. Table 2 provides additional information on the sources and uses of electricity in breweries. The largest uses are in machine drives for pumps, compressed air and brewery equipment $(46 \%)$, and for process cooling $(32 \%)$. The on-site combined production of heat and power accounts for $22 \%$ of total electricity sources; a significant share especially when compared to other industries in the U.S. Available information on fuel use is not as detailed. The vast majority of thermal energy is consumed in the form of steam at the brewhouse and for pasteurization.

Table 1. 1994 Primary Energy Consumption and Energy Expenditures in Malt Beverages

\begin{tabular}{lcccc}
\hline & \multicolumn{2}{c}{ Consumption } & \multicolumn{2}{c}{ Expenditures } \\
& TBtu & $(\%)$ & \$Million & $(\%)$ \\
\hline Net electricity (purchased) & 8 & $12 \%$ & 123 & $56 \%$ \\
Electricity losses & 16 & $24 \%$ & -- & -- \\
Distillate fuel oil & 0 & $0 \%$ & 0.5 & $<1 \%$ \\
Natural gas & 22 & $33 \%$ & 59 & $27 \%$ \\
Coal & 17 & $25 \%$ & 28 & $13 \%$ \\
Other fuels & 4 & $6 \%$ & 11 & $5 \%$ \\
\hline Total & $\mathbf{6 7}$ & $\mathbf{1 0 0 \%}$ & $\mathbf{2 2 1}$ & $\mathbf{1 0 0 \%}$ \\
\hline
\end{tabular}

Table 2. Uses and Sources of Electricity in the Brewery Sector, 1994

\begin{tabular}{lll}
\hline Uses & Million kWh & Percent \\
\hline Boiler/hot water/steam generation & 59 & $2 \%$ \\
Process cooling/refrigeration & 943 & $32 \%$ \\
Machine drive (pumps, compressors, motors) & 1,360 & $46 \%$ \\
Facility HVAC & 201 & $7 \%$ \\
Lighting & 214 & $7 \%$ \\
Other & 198 & $7 \%$ \\
Total & 2,975 & $100 \%$ \\
\hline Sources & Million kWh & \\
\hline Purchases & 2,323 & $78 \%$ \\
Cogeneration & 644 & $22 \%$ \\
Other (on-site generation) & 8 & $<1 \%$ \\
Total & 2,975 & $100 \%$ \\
\hline
\end{tabular}

${ }^{1}$ The compressed air system requires up to only $6 \%$ of the brewery's electrical energy requirements, hence, it is often a utility which receives little attention.

Energy intensity reflects the amount of energy required per unit of output or activity. Production volumes in the brewery industry are commonly expressed in barrels (US) or hectoliters (100 1) (elsewhere). A barrel is equivalent to 31 gallons or 0.85 hectoliter. Figure 1 identifies average energy intensities for beer production for the U.S. and other countries. Figure 1 indicates, there is a wide variation in energy intensity. The variation in intensities is partly influenced by the type of beer being produced. In the United Kingdom for example, a majority of beer produced is draught beer (almost 80\%) which has lower energy requirements than other types of beer since it is not pasteurized. The process is conducted at warmer temperatures (relative to lager brewing processes) and the total process time is much shorter (less refrigeration required). Further, energy intensities will also vary depending on the size of the brewery. Large breweries (greater than 500,000 hL annual production) use less energy per unit output. Recent data published on German breweries indicated that for large breweries (greater than $500,000 \mathrm{hL}$ ), primary energy consumption averaged $278 \mathrm{kBtu} /$ barrel $(69.5 \mathrm{kWh} / \mathrm{hL})$ while for small breweries (less than 20,000 hL), primary energy consumption was much higher $(476 \mathrm{kBtu} / \mathrm{bbl}$ or 119 
$\mathrm{kWh} / \mathrm{hL}$ ) (5). Primary energy intensity for US breweries was $335 \mathrm{kBtu} /$ barrel $(83.8 \mathrm{kWh} / \mathrm{hL})$ in 1994 (5). In this study we assumed the primary energy intensity for US breweries to be 335
kBtu/barrel (83.8 kWh/hL), $212 \mathrm{kBtu} /$ barrel (53 $\mathrm{kWh} / \mathrm{hL})$ in fuel and $122 \mathrm{kBtu} /$ barrel $(30.5 \mathrm{kWh} / \mathrm{hL})$ in electricity (in primary energy) (5). Boiler efficiency is assumed to be $85 \%$ on average.

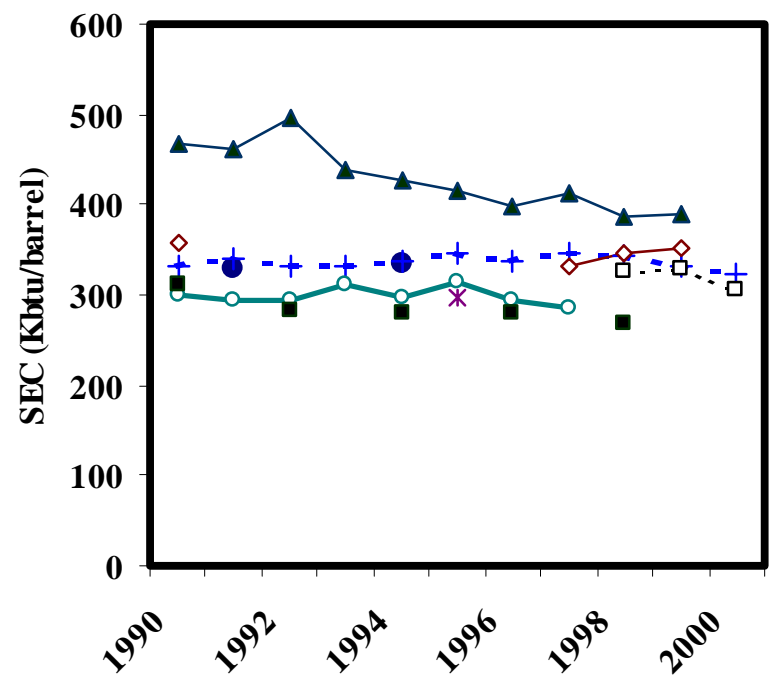

- U.S.

- -+ - Anheuser-Busch (US)

- - - - - - Coors (US)

$\longrightarrow$ Canada

* Austria

$\multimap$ Asahi (Japan)

- - Germany

- United Kingdom

Figure 1. Physical primary energy intensities for beer production for selected countries and companies (kBtu/barrel).

\section{ENERGY EFFICIENCY IMPROVEMENT}

In this section we briefly describe the energy efficiency opportunities that we have identified for breweries. We have gathered this information primarily from the technical and trade literature, discussions with industry, and information from vendors and suppliers. Due to the extent and wide variety of industry sources used we will only refer to the original report for a more extensive discussion and listing of sources $(5,6)$. Not all of the descriptions may be applicable to an individual brewery. A brewery's choice of technology and the operational parameters of that technology are determined in large part by the standards for product quality and uniformity. In addition, this list is not presumed to be exhaustive and additional opportunities may exist. Although we have focused on energy efficiency measures, it is important to note that the reduction of raw materials needed or the reduction of product loss results in the indirect reduction in energy use. For example, the reduction of beer wastes can reduce the need for processing an equivalent amount of raw materials, thereby resulting in energy savings. While materials efficiency measures can also reduce energy consumption in breweries, they are not specifically addressed in this study (5).

A variety of opportunities may exist within breweries to reduce energy consumption while maintaining or enhancing quality and productivity of the plant. Table 3 lists the energy efficiency measures that we identified. We categorized the measures as utilities (e.g. boilers and steam distribution, refrigeration and cooling) and process specific (e.g. mashing and lauter tun, wort boiling and cooling, fermentation, processing, and packaging). The values presented in this review provide an average estimate; only a detailed study of a specific location can produce reliable estimates for that plant. Actual energy savings may vary by plant and operation characteristics. Where possible, we provide an estimate of the range of savings found under varying conditions. We acknowledge that for some measures, particularly new technologies, there may not be sufficient information (e.g. a larger set of experiences) to estimate average industry savings and payback. For these, we have provided the information that was available. We also acknowledge that paybacks vary from country to country and for newer breweries versus older breweries. To account for these differences, we sought comments from US brewers and adjusted our ranges to incorporate their findings. Table 3 also summarizes the estimated payback and specific primary energy savings for each measure. Again, we note that savings and paybacks will vary for specific breweries depending on plant configuration, size, and utility rates. 
Table 3. Specific primary energy savings and estimated paybacks for efficiency measures

\begin{tabular}{|c|c|c|c|c|c|}
\hline \multicolumn{3}{|c|}{ Utilities } & \multicolumn{3}{|c|}{ Process specific } \\
\hline Measure & $\begin{array}{c}\text { Payback } \\
\text { (Years) } \\
\end{array}$ & $\begin{array}{l}\text { Primary Energy } \\
\text { Savings }^{\mathrm{A}} \\
\text { (kBtu/barrel) } \\
\end{array}$ & Measure & $\begin{array}{c}\text { Payback } \\
\text { (Years) }\end{array}$ & $\begin{array}{l}\text { Primary Energy } \\
\text { Savings } \\
\text { (kBtu/barrel) } \\
\end{array}$ \\
\hline \multicolumn{3}{|l|}{ Boilers and Steam distribution ${ }^{B}$} & \multicolumn{3}{|l|}{ Mashing and Lauter Tun } \\
\hline Maintenance & $<1$ & 4 & Waste heat recovery & $\mathrm{n} / \mathrm{a}$ & limited data \\
\hline Improved process control & $<1$ & 3 & Use of compression filter & 2 & 19 \\
\hline Flue gas heat recovery & $>3$ & 2 & Wort boiling and cooling & & \\
\hline Blowdown steam recovery & 2.7 & $2-3$ & Vapor condensers & $<2$ to 5 & $<1-22$ \\
\hline Steam trap maintenance & $<1$ & 3.4 & Thermal vapor recompression & $>2$ & $16-18$ \\
\hline Automatic steam trap monitoring & $<1$ & $<1$ & Mechanical vapor recompression & $\mathrm{D}$ & 23 \\
\hline Leak repair & $<1$ & 6 & Steineker Merlin system & 2 & 31 \\
\hline Condensate return & $>1$ & $19-21$ & High gravity brewing & $<1$ & $13-22$ \\
\hline Insulation of steam pipes & 1 & $6-28$ & Low pressure wort boiling & $\mathrm{n} / \mathrm{a}$ & $32-40$ \\
\hline Process integration & D & $47-84$ & Wort stripping & $\mathrm{n} / \mathrm{a}$ & $20-42$ \\
\hline \multicolumn{3}{|l|}{ Motors and Systems Using Motors ${ }^{\mathrm{C}}$} & Wort cooling & 3 & 17 \\
\hline Variable speed drives & 2 to 3 & $6-25$ & \multicolumn{3}{|l|}{ Fermentation } \\
\hline Downsizing & 2 & $1-2$ & Immobilized yeast fermenter & $\mathrm{n} / \mathrm{a}$ & limited data \\
\hline High efficiency & 1 to 2 & $1-2$ & Heat recovery & $>2$ & limited data \\
\hline \multicolumn{3}{|l|}{ Refrigeration and cooling ${ }^{\mathrm{C}}$} & New $\mathrm{CO}_{2}$ recovery systems & $>2$ & limited data \\
\hline $\begin{array}{l}\text { Better matching of cooling } \\
\text { capacity and cooling loads }\end{array}$ & 3.6 & $1-2$ & \multicolumn{3}{|l|}{ Processing } \\
\hline $\begin{array}{r}\text { Improved operation of ammonia } \\
\text { cooling system } \\
\text { Improved operations and }\end{array}$ & 5.5 & $<1-2$ & Microfiltration & 2 to 4 & limited data \\
\hline maintenance & $<1$ & 4 & Membranes (alcohol-free) & 4 & 19 \\
\hline $\begin{array}{r}\text { System modifications and } \\
\text { improved design }\end{array}$ & $\leq 3$ & $5-8$ & Heat recovery-pasteurization & $\mathrm{n} / \mathrm{a}$ & 1 \\
\hline Insulation of cooling lines & $\mathrm{n} / \mathrm{a}$ & Limited data & Flash pasteurization & $\mathrm{n} / \mathrm{a}$ & $6-14$ \\
\hline \multicolumn{3}{|l|}{ Other utilities } & \multicolumn{3}{|l|}{ Packaging } \\
\hline Lighting & $<2$ to 3 & $2-6$ & Heat recovery washing & $\leq 3$ & 6 \\
\hline Reduce space heating demand & $\mathrm{n} / \mathrm{a}$ & 8 & Cleaning improvements & 3.4 & 23 \\
\hline Anaerobic waste water treatment & $>2$ & $5-9$ & & & \\
\hline Membrane filtration wastewater & $\leq 5$ & limited data & & & \\
\hline Control \& monitoring systems & $<1-5$ & $<1-37$ & & & \\
\hline Combined heat and power & 3.5 & $67-100$ & & & \\
\hline Engine driven chiller systems & 2 to 4 & 12 & & & \\
\hline CHP with absorption cooling & 4.5 & 79 & & & \\
\hline \multicolumn{6}{|c|}{$\begin{array}{l}\text { A Primary energy savings account for savings in fuel use, electricity use, and electricity transmission and distribution losses. We use } \\
\text { a conversion factor of } 3.08 \text { from final to primary electricity use based on average US power plant heat rates. Energy savings are } \\
\text { primarily taken from data from case studies in the literature. To convert kBtu/barrel to } \mathrm{kWh} / \mathrm{hL} \text { use the conversion factor } 0.25 \\
\mathrm{kWh} / \mathrm{hL} / \mathrm{kBtu} / \mathrm{barrel} \text {. To convert } \mathrm{kBtu} / \mathrm{barrel} \text { to } \mathrm{GJ} / \mathrm{hL} \text {, use the conversion factor } 0.0009 \mathrm{GJ} / \mathrm{hL} / \mathrm{kBtu} / \mathrm{barrel}\end{array}$} \\
\hline \multicolumn{6}{|c|}{$\begin{array}{l}\text { B We assume an average US brewery fuel usage of } 212 \mathrm{kBtu} / \mathrm{barrel}(53 \mathrm{kWh} / \mathrm{hL}), 90 \text { to } 100 \% \text { of the fuel is used in the boilers, and } \\
\text { an average boiler conversion efficiency of } 85 \% \text {. We estimate a total plant electricity consumption of } 122 \mathrm{kBtu} / \mathrm{barrel}(30.5 \mathrm{kWh} / \mathrm{hL}) \text {. } \\
\mathrm{C} \text { We assume motors and systems using them make up } 46 \% \text { and process cooling make up } 32 \% \text { brewery electricity use [33]. } \\
\text { D Results vary widely depending on plant configuration and size of the brewery } \\
\text { n/a Paybacks for this measure could not be estimated from available data }\end{array}$} \\
\hline
\end{tabular}


Energy efficiency measures in boilers and steam distribution include maintenance and controls, steam or heat recovery and process integration. By using process integration, the Valaisanne brewery (Switzerland) saved $25 \%$ of the brewery's primary energy (84 kBtu/barrel, $21 \mathrm{kWh} / \mathrm{hL}$ ) (5). Miller's Milwaukee brewery (US) undertook several measures to improve their steam system, including steam trap maintenance, flue gas heat recovery, and improved process controls (5).

Improvements in motor and the systems that use them include downsizing of motors to match load requirements, introducing variable speed drives (VSD) and upgrading to better designed motors, pumps, and compressors. All of these measures have short payback periods of fewer than three years. The Romford brewery (UK) installed a VSD and achieved a $45 \%$ reduction in motor power use (5). Each system and corresponding motor is unique, and a financial analysis must be performed on each motor and its use to determine if upgrades are cost effective. Assuming $46 \%$ of electricity is spent on machine drive in the US (see Table 2), energy savings would result in specific energy savings of $6 \mathrm{kWh} / \mathrm{hL}$. Other data suggests a lower potential for energy savings, equivalent to $1.5 \mathrm{kWh} / \mathrm{hL}$ on average for all breweries (5). The former Stroh's Heileman Brewery (US) reported energy savings with a return on investment of over $200 \%$ for downsizing a pump motor (5). Others report specific energy savings of 0.25-0.5 kWh/hL for downsizing motors (5). The use of higher efficiency motors, pumps, and system components increase service factors, create longer bearing and insulation life, and produce less vibration.

Refrigeration and cooling system improvements include reducing the compressor size to match the load, improved operations and maintenance, insulation of the cooling lines and improved design. Energy savings for these measures range from 0.25 to $2 \mathrm{kWh} / \mathrm{hL}$, and many have additional benefits. Glycol cooling systems seem to be the most common systems for medium to large breweries. However, for those with ammonia systems, the ammonia system improvement measure can save up to $0.5 \mathrm{kWh} / \mathrm{hL}$, while reducing the oil leaving the compressor, increasing the lifetime of the cooling system and reducing operation and maintenance costs (5). Systems modifications on some cooling systems often simplify it, by eliminating a step in the cooling process and reduce water use with direct ammonia cooling systems there is always concern about the potential for ammonia leakage directly into the product.
Energy saving measures for refrigeration and cooling are based on a number of case studies, including the Grolsch brewery (the Netherlands), Bavaria brewery (the Netherlands), Heineken s'Hertogenbosch brewery (the Netherlands), New Belgium Brewery (US), the Miller Brewing Company (US), and Heineken Zoeterwoude (the Netherlands) (5).

Energy efficiency measures listed under other utilities in Table 3 refer to upgrades in lighting, reduction in space heating demand, applying anaerobic or membrane technologies for wastewater treatment, installation or upgrades in the brewery control and monitoring systems, and installation of combined heat and power systems (CHP). CHP systems are being used successfully in many industries that have semi-continuous process heating or cooling and electricity requirements. The Belhaven Brewery Group (Scotland) brews around 70,000 barrels of ales and lagers each year (5). They installed a new CHP unit operating around the clock to generate $300 \mathrm{~kW}$ of electricity and $500 \mathrm{~kW}$ of heat, around $70 \%$ of the brewery's total electricity needs, as well as providing heat for a variety of processes at the site. By installing the CHP systems, the Belhaven Brewery Group reduced primary energy use by over $30 \%$. Coors's Golden, Colorado brewery (US) produces more than 20 million barrels of malt beverages per year. In 1995, Coors teamed up with Trigen Energy Corporation and Nations Energy Corporation to set up a CHP system at this brewery. In addition to the reliable energy source CHP provided, they realized $20 \%$ specific primary energy savings (5). When combined with absorption cooling, the Asahi brewery in Suita (Japan) was able to save $14 \%$ in fuel demand and $40 \%$ in electricity requirements, a primary specific energy savings equivalent to $79 \mathrm{kBtu} /$ barrel $(20 \mathrm{kWh} / \mathrm{hL})(5)$.

"Other" utility efficiency measures also achieve nonenergy benefits in addition to large energy savings. Lighting retrofits can increase productivity and the attractiveness of the workplace. Anaerobic waste systems reduce wastewater, solid waste and sewer charges, cutback in sludge production and disposal, potentially reduce capital requirements, and improve control. Membrane filtration systems occupy less space than traditional settling and filtration systems. Control and monitoring systems can reduce the time to perform certain complex tasks and improve product consistency/quality (see Table 4). Note that the payback periods listed in Table 4 may vary with energy prices and other costs in these countries. Costs and payback period will be different for US breweries due to the US' lower energy costs. 
Table 4. Energy efficiency measures for other utilities in breweries. N/A denotes that no additional information was available for this study.

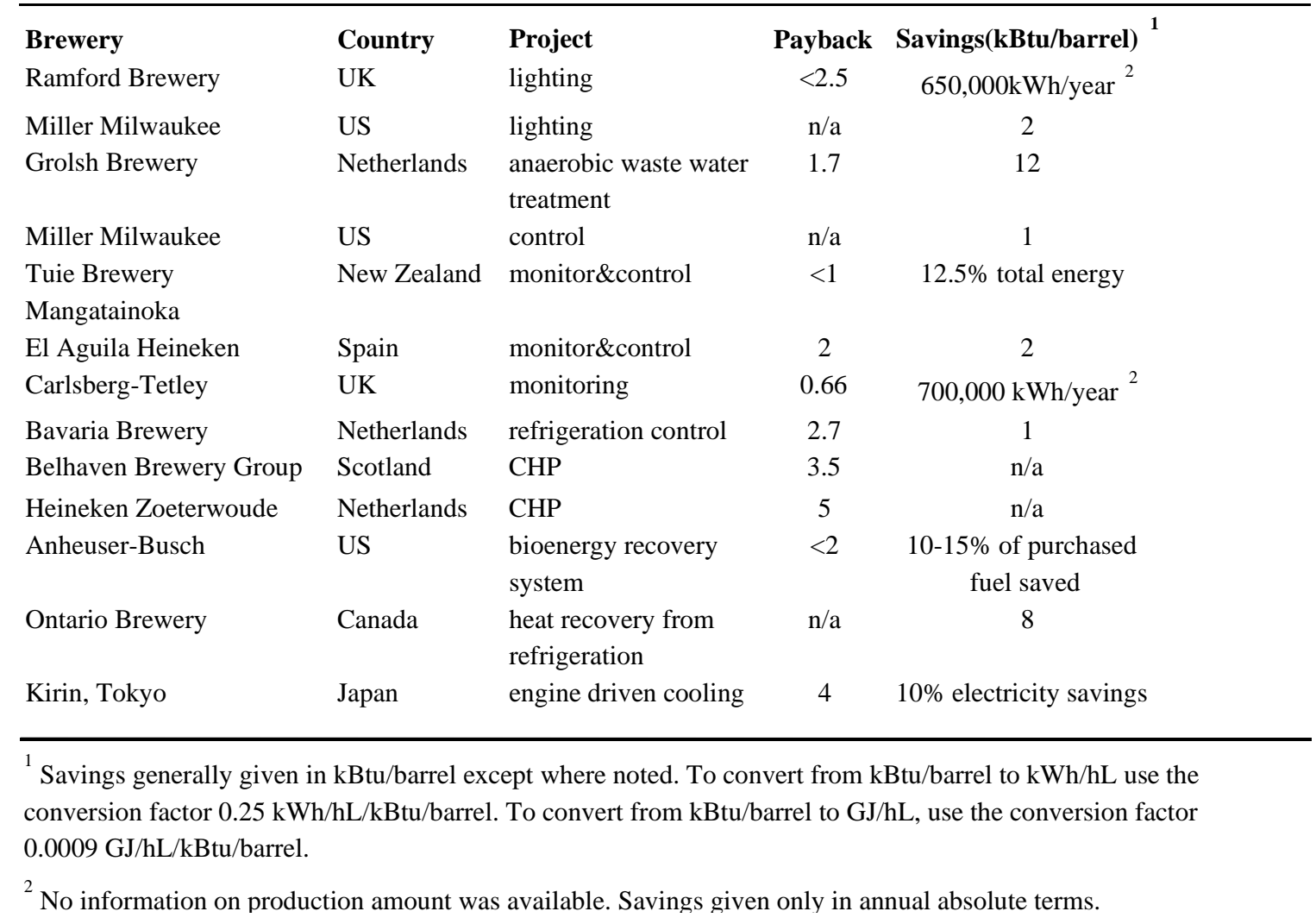

The most fuel intensive stage of brewing is the brewhouse, given the high steam requirements for mashing and wort boiling. Electricity use is high because of its demand in operation of the cooling systems for fermentation and operation of machine drives in the plant. In the brewhouse, it is possible to recover low-grade heat from the mash or the hot water tank used in the mashing (5). Another possibility for saving energy during mashing is through the use of compression filters instead of plate filters. The Brand Brewery (the Netherlands) saved 5 $\mathrm{kWh} / \mathrm{hL}$ applying this measure. In addition, proponents of this measure claim the use of compression filters reduces cleaning costs, increases yield, saves water, reduces cycle times, reduces spent grain moisture, increases wort concentration, and hence, increases productivity. The potential impact on taste is something that must be further evaluated. We acknowledge that while this technology is new and its uptake will take time, sufficient data is not yet available to support all claims.

Within the wort boiling and cooling step, many opportunities exist for recovering thermal energy for use in other brewery operations, either by minimizing evaporation requirements (evaporation requirements are dictated by taste), recovering heat from vapor condensate or more efficient heat recovery (from wort cooling). Developments in kettle and brewhouse technology include thermal or mechanical vapor recompression, low pressure wort boiling, high gravity brewing, wort stripping and other system configurations. Steineker has developed a system called the Merlin system. Using the Merlin brew kettle, operated with an external combustion system and open evaporation, the Scherdel brewery at Hof (Germany) found potential savings of $31 \mathrm{kBtu} / \mathrm{barrel}$ (5). In addition to energy savings, proponents claim that the Steineker-Merlin system may improve product quality by reducing carmelization and fobbing, provide more brews between cleanings and realize better vessel utilization. Taste and analytical implications on each specific brand of beer should be studied before such a drastic change in boiling can be installed. High gravity brewing is a more common technology incorporated in the majority of breweries in the US, perhaps because of its many advantages. It increases brewing capacity with more efficient use of plant facilities, may improve product quality (better consistency and character have been reported, 
although the impact on flavor is an obvious concern), increases flexibility of beer type and productivity, reduces water use, lowers labor and cleaning costs and defers capital expenditures. Anheuser-Busch (US) has implemented high gravity to gain brewery capacity. Wort stripping provides shorter cooking times for the wort and significant reductions in evaporation requirements with no changes in color, foam, stability. Heat recovery from wort cooling systems, when combined with water reuse in mashing, bottle washing or cleaning, can reduce water use. Breweries using vapor condensers in the Netherlands and in the US reported reduced water and operations and maintenance costs in addition to energy savings (5). Users have found that thermal vapor recompressors reduce the need for a circulation pump and reduce boiling times. Manufacturers claim mechanical vapor recompressors reduce aroma emissions almost entirely, provide a gentler boiling process and save in steam, in many cases.

Energy efficiency measures in the fermentation step include the use of immobilized yeast, heat recovery systems and carbon dioxide $\left(\mathrm{CO}_{2}\right)$ recovery systems. While immobilized yeast technologies are currently being perfected, they have been tested at a pilot plant and were found to reduce yeast reactor time significantly, i.e. from weeks to hours (5). With this technology, Meura-Delta (Belgium) has refined the fermentation process from five to seven days down to one day. In addition, immobilized yeast technology has been found to improve process quality control and reduce materials through the reuse of yeast and the reduction in kieselguhr required for filtration in the process. Implementing immobilized yeast technologies, however, may affect the flavor of the beer. Heat recovery systems may be expensive and limited data exists for these systems. Vendors estimate the payback period for carbon dioxide recovery systems to be 2 to 3 years from energy savings alone. Anheuser-Busch, however, estimates paybacks to be longer for $\mathrm{CO}_{2}$ recovery systems for US breweries, based on lower cost of domestic $\mathrm{CO}_{2}$. $\mathrm{CO}_{2}$ recovery systems are fairly common for large breweries, but advances in the technology are making them more attractive for medium and small breweries. In addition to the energy savings, manufacturers claim that compared to the traditional technology used, $\mathrm{CO}_{2}$ recovery technology saves $\mathrm{CO}_{2}$, requires less capital, has much lower operation and maintenance costs, eliminates recirculation pumps, and saves $50 \%$ of the water in scrubbing systems.

Part of beer conditioning is removing all remaining unwanted bacteria before bottling, usually through pasteurization. Improvements in pasteurization include tunnel or flash pasteurization and heat recovery. Heat recovery in pasteurization has been reported to save $1 \mathrm{kBtu} /$ barrel of primary energy. Flash pasteurization has been reported to reduce energy by two thirds compared to tunnel pasteurization, a primary energy savings of 6 to 14 $\mathrm{kBtu} / \mathrm{barrel}$. In addition to energy savings, flash pasteurization has been found to require less space and coolant, lower initial investment and lower operation and maintenance costs. Since flash pasteurization is integrally linked to the purchase and use of sterile filling technology, however, the use of flash pasteurization includes significant additional costs associated with sterile filtration requirements.

An alternative to pasteurization is the use of sterile filtration in cross flow membrane filtration technologies. Though limited data exists for energy savings from oscillating microfiltration systems, investigations found potential $15-40 \%$ savings compared to standard steady-flow microfiltration (5). This technology is new to the brewery industry, but is being investigated for its potential energy savings as well as savings on disposal costs and reduction of waste (5). However, some believe current cross flow membrane filtration systems may require as much extra energy as they save.

The processing stage is also the stage where alcohol is removed for non-alcoholic beer. The use of membranes is seen to be the most promising technology in the long term for production of nonalcoholic beer and has significant energy savings as well. The Heineken brewery at s'Hertogenbosch (the Netherlands) reported specific primary energy savings of $19 \mathrm{kBtu} /$ barrel when upgrading from an early model membrane system to a more advanced system. Potential savings for new membrane system installations could be higher. Heineken also reported savings of 24 million liters per year of water and a payback of 4 years.

In packaging, the final stage of brewing, energy savings can be attained through heat recovery from bottle washing and keg washing, as well as from cleaning efficiencies. Some estimate energy savings at $6 \mathrm{kBtu} / \mathrm{barrel}$ for heat recovery washing, with paybacks of three years or less (5). In addition to the energy savings in heat recovery, water use was reduced by $40 \%$. Moosehead breweries (Canada) have successfully applied this measure. The Brand Brewery at Wijlre (the Netherlands) cleans and reuses its bottles with great success. They save 23 $\mathrm{kBtu} / \mathrm{barrel}(6 \mathrm{kWh} / \mathrm{hL})$, and, in addition, reduce waste. Their project had a payback of 3.4 years. 
Breweries in the United States spend annually over $\$ 200$ Million on energy. Energy consumption is equal to $3-8 \%$ of the production costs of beer, making energy efficiency a potential way to reduce and control production costs. We found energy efficiency improvement opportunities in the brewery industry, both for utilities and for specific processes. Using utility energy efficiency measures that do not interfere directly with the brewing process show potential promise for cost-effective energy savings. For process specific measures, some new technologies both reduce energy and may improve product quality (either in quality or yield). Specific primary energy savings are provided for each energy efficiency measure based on case studies that described implementation of the measures as well as technical literature. Other opportunities for materials efficiency and waste prevention, as well as emerging technologies exist, but are not discussed in depth in this paper. Our findings suggest that there are some opportunities to reduce energy consumption costeffectively for breweries. Many of the evaluated energy efficiency measures not only save energy, but they do so within a short payback period, and accrue other benefits as well, such as reduced carbon dioxide emissions, reduced waste or reduced water use. However, each measure must be studied individually to determine if there are any detrimental affects to quality and taste of the beer. Further research on the applicability of energy efficient technologies to different brewing practices as well as economic analysis of the measures is needed.

\section{ACKNOWLEDGEMENTS}

This work was supported by the Climate Protection Partnerships Division, Office of Air and Radiation, U.S. Environmental Protection Agency through the U.S. Department of Energy Contract No. DE-AC0376SF00098. The authors of this report would like to thank Anheuser-Busch, Coors, Miller, Labbats, and the New Belgium Brewing Company for sharing their expertise and information on brewing, comments, and review. We also thank Paul Kidger, Tom Lom of Lom and Associates, Charlie Bamforth from the University of California at Davis, and the people at Burnett and Rolfe for their comments and review. Despite their efforts any remaining errors are the responsibility of the authors.

\section{REFERENCES}

1. Department of Commerce (DOC), U.S. Bureau of the Census. 1999. 1997-Economic Census Breweries, Manufacturing Industry Series. EC97M-3121D.

2. Energy Information Administration (EIA), U.S. Department of Energy. 1997. Manufacturing Consumption of Energy 1994. Washington, DC.

3. Department of Commerce (DOC). (2000). Annual Survey of Manufacturers. http://www.census.gov/econ/www/ma0300.html

4. Schu et al. 1999. Verfahrenskombination im Sudhaus-Neues Würzekochsystem und Externe Würzeerhitzung. Brauwelt 32 pp.1424-1430.

5. Galitsky, C., Martin, N., Worrell, E., Lehman, B. 2002. Energy Efficiency Opportunities and Potential Cost Savings for United States Breweries, Berkeley, CA: Lawrence Berkeley National Laboratory (forthcoming).

6. Galitsky, Christina, Martin, N., Worrell, E. 2001. Energy Efficiency Opportunities and Potential Cost Savings for United States Breweries MBAA Technical Quarterly 38 (4). 